\title{
THE METHOD OF PLANNING THE IMPLEMENTATION OF RAILWAY INVESTMENTS INCLUDING RISK
}

\author{
J. KOWALSKI ${ }^{1}$, M. POLOŃSKI ${ }^{2}$
}

\begin{abstract}
Almost every construction investment should contain elements of risk forecasting, whose validity depends, among other things, on the correct assessment of potential threats. These risks were defined by the Authors as risk factors that were characterized and then grouped on the basis of performed research in the scope of their identification. Due to lack of method of scheduling railway investments on the construction market, including risk assessment, a research effort was undertaken [14-17], the result of which is the proposed method. The article presents the main assumptions of the original method of rail investment planning, which on the one hand, will take into account the impact of potential threats identified previously by the Authors, and, on the other, will allow project managers to refer to the conditions in which the implementation of a specific facility is planned. The assumption was made that the method, relatively easy to implement, supported by an appropriate computational program, will encourage teams planning the implementation of railway undertakings to its application and will improve the reliability of the schedules they develop.
\end{abstract}

Keywords: threat identification, risk, railway investments, planning of construction works, risk matrix.

\section{INTRODUCTION}

The construction market offers various methods of risk management. The most known are risk management according to Prince 2 and PMBOK. PMBOK (The Project Management Body of Knowledge) contains six basic processes: 1. Risk management planning, 2. Risk identification, 3. Qualitative risk analysis, 4. Quantitative risk analysis, 5. Risk response planning, 6. Monitoring and risk control. According to Skorupka [9], this method can be applied in various disciplines,

\footnotetext{
${ }^{1}$ PhD. student, Warsaw University of Life Science - SGGW, Faculty of Civil and Environmental Engineering, Nowoursynowska 159,02-776Warsaw, Poland, e-mail: jan_kowalski@sggw.pl

${ }^{2}$ DSc., PhD., Eng., Warsaw University of Life Science - SGGW, Faculty of Civil and Environmental Engineering, Nowoursynowska 159,02-776Warsaw, Poland, e-mail: mieczyslaw_polonski@sggw.pl
} 
for example in financial risk management, military risk management or construction risk management, and even in information risk management.

The PRINCE 2 method is a less popular one. The idea of the method is based on quality management. In its initial phase, key elements such as: product, service and production process, should be defined. The method is based on meticulous documentation. It fulfils a control function based on a series of checkpoints and increases the probability that no factor that affects the implementation of the undertaking will be neglected. Tasks, whose results do not meet the quality requirements or other evaluation criteria, must be performed again. The documentation prepared on an ongoing basis ensures that the requirements are met [9].

There are also other classic methods of planning the execution of construction works, which do not take into account or take into account to a small extent risk elements, for instance: CPM (Critical Path Method) network planning method, which is deterministic, PERT method (Program Evaluation and Review Technique) introducing element of time randomness execution of tasks, the GERT (Graphical Evaluation and Review Technique) method and the GERTS (Graphical Evaluation and Review Technique Simulation) method, which uses, among other things, random number generators, or the CYCLONE (Cyclic Operations Network) method [18].

Nevertheless, traditional methods are largely based on the experience and intuition of the people who use them. According to the Authors, in a situation when building objects are becoming more and more complex and investors' requirements as to the quality, time and cost of their implementation are constantly growing, this approach may lose its importance in the near future. During risk management, the most desirable are those methods that base their methodologies on reliable bases of already recognized risk factors including the specificity of planned works.

Since a search for a relatively simple, practically applicable construction risk management methods, is still ongoing, the Authors present the most important assumptions of the original method of scheduling railway investments. It takes into account the impact of potential, identified and previously classified threats, and then grouped on the basis of previous research [14-17]. The set of identified risk factors is presented in chapter 2 .

The science of risk is relatively new, and the terms applied are not always explicit, thus the Authors indicate the definitions of the basic concepts that they use in this article.

- risk - the possibility of occurring through our actions, abandonment or forces of nature predictable at a given time, negative consequences of an undesirable random event, the effect and probability of which we are able to estimate, 
- adverse event - is a measurable form of one or several risk factors, resulting in failure to achieve fully or not at all the intended purpose, and thus causing some loss,

- risk factor (threat) - a potential source of an adverse event that may or may not occur in the future.

\section{Model DesCription}

The presented method of risk assessment of railway investments is an original proposition. The basic assumption was to develop a method that is as effective and as simple as possible, the implementation of which, during the implementation of large railway undertakings will not require the collection of too many data and advanced calculations. Using the proposed method, the impact of identified risk factors on the implementation of a railway project can be assessed from the point of view of both Investors and Contractors. The risk assessment concerns the formulas for the "Design and Build" and "Build" contracts. The general assumption of the method is based on the correlation of risks previously identified by the Authors in the scale of the country during the implementation of railway investments with the specificity and conditions for the implementation of newly planned investments.

The ideological model of the method presents successive calculation steps assigned to the two main blocks. (Figure 1). The first of them is a constant block that cannot be changed during its implementation. It contains the key identified risk factors and their initial quantitative assessment. The second block is variable and the risk assessments adopted in it largely depend on the decisions of the personnel creating the schedule. In the proposed method, the main reasons for the quantitative assessment of parameters in this block is a detailed analysis of the contract documentation, the identification of the conditions under which the planned investment will be implemented and a realistic assessment of potential risk factors carried out by the implementation team.

Finally, the team performs a comprehensive assessment of the impact of each risk factor identified by the Authors of the method on the contract and their correlation with individual tasks included in the structure of the WBS schedule. It is assumed that the allocated risks will affect directly the time and / or cost of the actual schedule tasks, and through the tasks of a total WBS structure on the entire schedule. This way of identifying the impact of individual risk factors on subsequent tasks requires a certain amount of work by the planning team, but it is necessary if trying to take into account the real risk of the planned investment. 


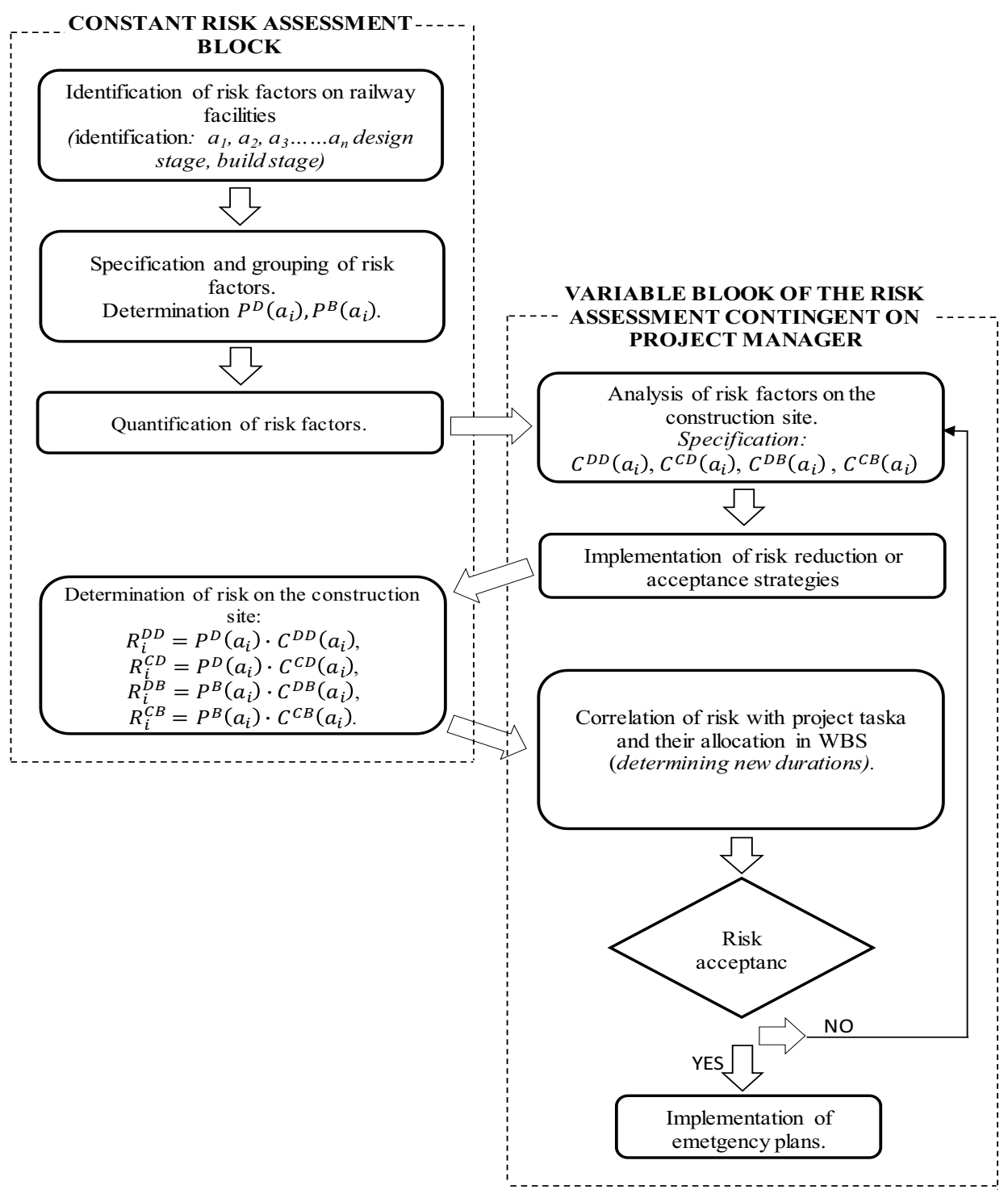

Fig. 1. Ideological model of the proposed risk assessment method . Source: Own study.

Combining the allocation of risk factors with the structure of the WBS schedule is an original proposal for scheduling rail investments. The method, through a detailed risk correlation with the 
appropriate subtasks of the WBS structure, will allow to determine the most probable completion dates and costs of individual stages of works and the entire construction project. The method does not interfere with the strategy of implementing emergency plans. The development of such plans and their implementation are left to the staff of the Contractor, Contract Engineer or Investor.

For editorial reasons, only the general outline of the proposed method is presented below. The presented method has already been subject to practical verification. It was made on the example of a railway contract implemented under the OPI \& E 7.1 - 9.1 project. The contract was carried out in accordance with the Yellow FIDIC Book procedures. The scope of works included modernization of three railway stations and selected route sections. The total gross contract amount was approx. PLN 525 million, and the planned completion date was 35 months.

The method of calculations and the results of the analyzes carried out will be presented in subsequent publications.

\subsection{IDENTIFICATION OF RISK FACTORS}

An analysis of risk factors identification based on domestic and international literature was carried out $[1-8,10-13,19-23]$. Contract documentation of one of the largest railway investments implemented in recent years in Poland, was also considered. A national survey was then carried out. The result of the above activities is a list of risk factors which, according to the conducted research, most often have the greatest impact on the course of works on railway contracts in Poland. Being aware of the simplifications that are necessary to generalize such a complex process as the risk analysis of a specific building, the list below is presented, divided into the design and implementation phase of the works.

At the design stage the following risk factors were identified:

- Procedural defects in preparation of tender documents,

- Improperly estimated deadline for the development of project documentation by the Commissioning party,

- Too many external institutions involved in the investment process,

- The necessity to make exceptions to the guidelines from the tender stage,

- Errors in the conceptual design documentation from the tender stage,

- Problems with obtaining current maps for project purposes from rail geodesic centers,

- Problems with reconciliation of project documentation with external Stakeholders, 
- Problems with reconciliation of project documentation with internal companies from the PKP ((Polish Investor) group,

- Problems with reconciliation of project documentation with the owners of technical infrastructure on the premises of PKP PLK (Polish Investor),

- Long-term procedures for agreeing project documentation within PKP PLK (Polish Investor),

- Problems with the acceptance of project documentation by the Contract Engineer,

- Commissioning Party don't have a set of legal documents regarding the area planned for the investment within the deadline,

- Obtaining the decision on building permits delayed due to the fault of the Commissioning Party,

- The decision on building permits delayed due to the Designer's fault?,

- The decision on building permits delayed due to the fault of the external unit, e.g. additional agreements.

At the build stage the following factors were identified:

- Errors in the preparation of tender documents (SIWZ, OPZ, PFU),

- Improperly estimated time of completion of the investment by the Employer,

- Too many external institutions involved in the investment process,

- Terms of the contract not adapted to the contract specificity (FIDIC Red, FIDIC Yellow, others),

- Badly estimated investment costs by the Contractor (financial problems of the Contractor),

- Difficulties in the preparation, in terms of formal, legal and technical areas for investment,

- Internal regulations of PKP PLK SA not coordinated with the provisions of contracts,

- Errors in project documentation,

- Problems with the supply of materials and other resources,

- Awarding shorter track closures to the contractor,

- Problems with outdated geodetic materials (numerous collisions with non-inventory of underground infrastructure). 


\subsection{QUANTIFICATION OF RISK FACTORS}

The next stage of the proposed method was to determine the quantitative assessment of individual risk factors. This was done on the basis of statistical analysis of the obtained research results and adopted assumptions. Presented below are the most important calculation formulas used.

First, the data was normalized. Individual normalized values were successively aggregated.

- The value standardised impact of the of each risk factor $Q D_{i}$ was calculated according to the following formula:

- Design stage

$$
\begin{aligned}
& \mathrm{QD}_{\mathrm{i}}^{\mathrm{D}}=\frac{\mathrm{QnD}_{\mathrm{i}}^{\mathrm{D}}}{\mathrm{I}^{\mathrm{D}}} \\
& \mathrm{QC}_{\mathrm{i}}^{D}=\frac{Q n c_{i}^{D}}{I^{D}}
\end{aligned}
$$

- Build stage

$$
\begin{aligned}
& \mathrm{QD}_{\mathrm{i}}^{B}=\frac{Q n D_{i}^{B}}{I^{D}} \\
& \mathrm{QC}_{\mathrm{i}}^{B}=\frac{Q n C_{i}^{B}}{I^{B}}
\end{aligned}
$$

where:

$\mathrm{QD}_{\mathrm{i}}^{\mathrm{D}}, \mathrm{QD}_{\mathrm{i}}^{\mathrm{B}}$ - relative impact of the i-th risk factor for the Design stage $\left(\mathrm{QD}_{\mathrm{i}}^{\mathrm{D}}\right)$ or Build $\left(\mathrm{QD}_{\mathrm{i}}^{\mathrm{B}}\right)$ affecting the investment duration,

$\mathrm{QC}_{\mathrm{i}}^{\mathrm{D}}, \mathrm{QC}_{\mathrm{i}}^{\mathrm{B}}$ - relative impact of the $\mathrm{i}$-th risk factor for the Design stage $\left(\mathrm{QC}_{\mathrm{i}}^{\mathrm{D}}\right)$ or Build $\left(\mathrm{QC}_{\mathrm{i}}^{\mathrm{B}}\right)$ affecting the investment cost,

$\mathrm{QnD}_{\mathrm{i}}^{\mathrm{D}}, \mathrm{QnD}_{\mathrm{i}}^{\mathrm{B}}$-impact of the i-th risk factor for the Design stage $\left(\mathrm{QnD}_{\mathrm{i}}^{\mathrm{D}}\right)$ or Build $\left(\mathrm{QnD}_{\mathrm{i}}^{\mathrm{B}}\right)$ affecting the investment duration,

$\mathrm{QnC}_{\mathrm{i}}^{\mathrm{D}}, \mathrm{QnC}_{\mathrm{i}}^{\mathrm{B}}$-impact of the i-th risk factor for the Design stage $\left(\mathrm{QnC}_{\mathrm{i}}^{\mathrm{D}}\right)$ or Build $\left(\mathrm{QnC}_{\mathrm{i}}^{\mathrm{B}}\right)$ affecting the investment cost,

$\mathrm{I}^{\mathrm{D}}, \mathrm{I}^{\mathrm{B}}$ - the number of surveys for the assessment of risk factors at the Design stage $\left(\mathrm{I}^{\mathrm{D}}\right)$ or Build $\left(\mathrm{I}^{\mathrm{B}}\right)$.

- The coefficient of variation of each risk factor was then calculated:

- Design stage

$$
\mathrm{V}_{\mathrm{i}}^{D}=\frac{S D_{i}^{D}}{M_{i}^{D}}
$$


- Build stage

$$
\mathrm{V}_{\mathrm{i}}^{B}=\frac{S D_{i}^{B}}{M_{i}^{B}}
$$

where:

$\mathrm{V}_{\mathrm{i}}^{\mathrm{D}}, \mathrm{V}_{\mathrm{i}}^{\mathrm{B}}$ - coefficient of variation of the i-th rating of the risk factor for the Design or Build stage,

$\mathrm{SD}_{\mathrm{i}}^{\mathrm{D}}, \mathrm{SD}_{\mathrm{i}}^{\mathrm{B}}$ - standard deviation of the assessment of the i-th risk factor for the Design or Build stage,

$M_{i}^{D}, M_{i}^{B}$ - average point estimate of the i-th risk factor for the Design or Build step on a 0-10 scale.

- The final weight of each risk factor calculated as:

- Design stage

$$
\begin{aligned}
W D_{i}^{D} & =Q D_{i}^{D} \cdot\left[M_{i}^{D}-\left(M_{i}^{D} \cdot V_{i}^{D}\right)\right] \\
W C_{i}^{D} & =Q C_{i}^{D} \cdot\left[M_{i}^{D}-\left(M_{i}^{D} \cdot V_{i}^{D}\right)\right.
\end{aligned}
$$

- Build stage

$$
\begin{aligned}
& W D_{i}^{B}=Q D_{i}^{B} \cdot\left[M_{i}^{B}-\left(M_{i}^{B} \cdot V_{i}^{B}\right)\right. \\
& W C_{i}^{B}=Q C_{i}^{B} \cdot\left[M_{i}^{B}-\left(M_{i}^{B} \cdot V_{i}^{B}\right)\right.
\end{aligned}
$$

where:

$\mathrm{WD}_{\mathrm{i}}^{\mathrm{D}}, \mathrm{WD}_{\mathrm{i}}^{\mathrm{B}}$ - weight value of the $\mathrm{i}$-th risk factor for the Design or Build stage phase affecting the investment duration,

$\mathrm{WC}_{\mathrm{i}}^{\mathrm{D}}, \mathrm{WC}_{\mathrm{i}}^{\mathrm{B}}$ - weight value of the $\mathrm{i}$-th risk factor for the Design or Build stage phase affecting the investment cost.

- The final normalized weight value of individual threats was calculated as:

- Design stage

$$
\begin{aligned}
\mathrm{WDn}_{\mathrm{i}}^{D}=\frac{W D_{i}^{D}}{\sum_{i=1}^{N^{D}} W D_{i}^{D}} & ; & \sum_{i=1}^{N^{D}} W D n_{i}^{D}=1 \\
\mathrm{WCn}_{\mathrm{i}}^{D}=\frac{W C_{i}^{D}}{\sum_{i=1}^{N^{D}} W C_{i}^{D}} & ; & \sum_{i=1}^{N^{D}} W C n_{i}^{D}=1
\end{aligned}
$$

- Build stage

$$
\mathrm{WDn}_{\mathrm{i}}^{B}=\frac{W D_{i}^{B}}{\sum_{i=1}^{N^{B}} W D_{i}^{B}} \quad ; \quad \sum_{i=1}^{N^{B}} W D n_{i}^{B}=1
$$




$$
\mathrm{WCn}_{\mathrm{i}}^{B}=\frac{W C_{i}^{B}}{\sum_{i=1}^{N^{B}} W C_{i}^{B}} \quad ; \quad \sum_{i=1}^{N^{B}} W C n_{i}^{B}=1
$$

where:

$\mathrm{WDn}_{\mathrm{i}}^{\mathrm{D}}, \mathrm{WCn}_{\mathrm{i}}^{\mathrm{D}}, \mathrm{WDn}_{\mathrm{i}}^{\mathrm{B}}, \mathrm{WCn}_{\mathrm{i}}^{\mathrm{B}},-$ normalized weight of the $\mathrm{i}$-th risk factor affecting the investment duration (WD) or cost (WC) for the Design $\left(\mathrm{n}_{\mathrm{i}}^{\mathrm{D}}\right)$ or Build $\left(\mathrm{n}_{\mathrm{i}}^{\mathrm{B}}\right)$ stage,

$\mathrm{i}-1 . . \mathrm{N}^{\mathrm{D}}, 1 . . \mathrm{N}^{\mathrm{B}}$ where $\mathrm{N}$ is number of identified risk factors in Design or Build stage.

- Risk assessment for particular risks:

- Design stage

- Build stage

$$
\begin{aligned}
& R_{i}^{D B}=P^{B}\left(a_{i}\right) \cdot C^{D B}\left(a_{i}\right) \\
& R_{i}^{C B}=P^{B}\left(a_{i}\right) \cdot C^{C B}\left(a_{i}\right)
\end{aligned}
$$

$$
\begin{aligned}
& R_{i}^{D D}=P^{D}\left(a_{i}\right) \cdot C^{D D}\left(a_{i}\right) \\
& R_{i}^{C D}=P^{D}\left(a_{i}\right) \cdot C^{C D}\left(a_{i}\right)
\end{aligned}
$$

where:

$\mathrm{R}_{\mathrm{i}}^{\mathrm{DD}}, \mathrm{R}_{\mathrm{i}}^{\mathrm{DB}}$ - risk of the $\mathrm{i}$-th factor for Design or Build stage affecting the investment duration [\%], $\mathrm{R}_{\mathrm{i}}^{\mathrm{CD}}, \mathrm{R}_{\mathrm{i}}^{\mathrm{CB}}$ - risk of the $\mathrm{i}$-th factor for Design or Build stage affecting the investment cost[\%],

$\mathrm{P}^{\mathrm{D}}\left(\mathrm{a}_{\mathrm{i}}\right), \mathrm{P}^{\mathrm{B}}\left(\mathrm{a}_{\mathrm{i}}\right)$ - the probability of occurrence of the $\mathrm{i}$-th risk factor. (Designated based on a nationwide survey). Stage of Design or Build,

$C^{D D}\left(a_{i}\right), C^{D B}\left(a_{i}\right)$ - a consequence of the influence of the $i$-th risk factor on the implementation of the undertaking made by the team implementing the given project, for Design $C^{D D}\left(a_{i}\right)$ or Build $C^{D B}\left(a_{i}\right)$ stage; affecting the investment duration [\%]

$C^{C D}\left(a_{i}\right), C^{C B}\left(a_{i}\right)$ - a consequence of the influence of the i-th risk factor on the implementation of the undertaking made by the team implementing the given project, for Design $\mathrm{C}^{\mathrm{CD}}\left(\mathrm{a}_{\mathrm{i}}\right)$ or Build $\mathrm{C}^{\mathrm{CB}}\left(\mathrm{a}_{\mathrm{i}}\right)$ stage; affecting the investment cost [\%]

- Weight assessment of the risk factor:

- Design stage

- Build stage

$$
\begin{aligned}
& \mathrm{W}_{\mathrm{Ri}}^{\mathrm{DD}}=R_{i}^{D D} * \mathrm{WDn}_{\mathrm{i}}^{D} \\
& \mathrm{~W}_{\mathrm{Ri}}^{\mathrm{CD}}=R_{i}^{C D} * \mathrm{WCn}_{\mathrm{i}}^{D}
\end{aligned}
$$

$$
\mathrm{W}_{\mathrm{Ri}}^{\mathrm{DB}}=R_{i}^{D B} * \mathrm{WDn}_{\mathrm{i}}^{B}
$$$$
\mathrm{W}_{\mathrm{Ri}}^{\mathrm{CB}}=R_{i}^{C B} * \mathrm{WCn}_{\mathrm{i}}^{B}
$$ 
where:

$\mathrm{W}_{\mathrm{Ri}}^{\mathrm{DD}}, \mathrm{W}_{\mathrm{Ri}}^{\mathrm{DB}}$ - index of the weight-based risk assessment for the i-th factor at the stage Design or Build; affecting the investment duration [\%],

$\mathrm{W}_{\mathrm{Ri}}^{\mathrm{CD}}, \mathrm{W}_{\mathrm{Ri}}^{\mathrm{CB}}$ - index of the weight-based risk assessment for the i-th factor at the stage Design or Build; affecting the cost investment [\%],

- Total weighted risk:

- Design stage

$$
\begin{aligned}
S^{D D} & =\sum_{i=1}^{N^{D}} R_{i}^{D D} * \mathrm{WDn}_{\mathrm{i}}^{D} \\
S^{C D} & =\sum_{i=1}^{N^{D}} R_{i}^{C D} * \mathrm{WDn}_{\mathrm{i}}^{D}
\end{aligned}
$$

- Build stage

$$
\begin{aligned}
& S^{D B}=\sum_{i=1}^{N^{B}} R_{i}^{D B} * \mathrm{WDn}_{\mathrm{i}}^{D} \\
& S^{C B}=\sum_{i=1}^{N^{B}} R_{i}^{C B} * \mathrm{WDn}_{\mathrm{i}}^{D}
\end{aligned}
$$

where:

$\mathrm{S}^{\mathrm{DD}}, \mathrm{S}^{\mathrm{DB}}$ - total weighted risk at the level of a construction project at the Design or Build stage; affecting the investment duration [\%],

$\mathrm{S}^{\mathrm{CD}}, \mathrm{S}^{\mathrm{CB}}$ - total weighted risk at the level of a construction project at the Design or Build stage; affecting the cost investment [\%].

In order to facilitate the implementation of the necessary calculations, the Authors developed a special calculation sheet in Excel, which on the basis of user-defined data calculates the percentage index of weighting of individual risk factors, and new durations and / or costs of individual work stages. The obtained results are strictly dependent on the defined threats and the assessment of their occurrence and effects on the analysed project. A detailed description of the tool will be presented by the Authors in subsequent publications.

\subsection{RISK REDUCING STRATEGY}

The proposed method does not include risk reducing strategies. The Authors leave these issues to the project managers. The Authors do not impose any restrictions on the implementation of risk reducing strategies for a given project, but only indicate that the project manager at the planning stage according to the proposed method can accept certain risk factors, or return to their assessment. 


\subsection{APPLICATION OF THE PROPOSED METOD}

After identification and quantification of risk factors, they are correlated with specific operations in the process of implementing a construction project. Therefore, it is necessary to find answers which of the risk factors affect individual real tasks ${ }^{3}$ included in the schedule and its WBS structure (Table 1, Fig. 2). The assumption was made that risk factors will be directly correlated with actual rather than aggregate tasks. Such a solution will allow for a more accurate recognition of the impact of identified risk factors on the course of work on the planned object. Further calculations are presented on the example of task time, however the cost calculation is analogous.

Table 1. Correlation of real tasks of the summary task X with risk factors. Own study based on the source [9].

\begin{tabular}{|c|c|}
\hline Risk factors & $\begin{array}{c}\text { Correlation of risk factors with the schedule } \\
\text { (with real tasks) }\end{array}$ \\
\hline$a_{1}$ & $\mathrm{~A}, \mathrm{C}, \mathrm{H}$ \\
\hline$a_{2}$ & $\mathrm{C}, \mathrm{F}, \mathrm{G}$ \\
\hline$a_{3}$ & $\mathrm{~B}, \mathrm{C}, \mathrm{D}$ \\
\hline$a_{4}$ & $\mathrm{~A}, \mathrm{C}, \mathrm{E}$ \\
\hline$a_{5}$ & $\mathrm{C}, \mathrm{D}, \mathrm{E}$ \\
\hline$a_{6}$ & $\mathrm{D}, \mathrm{E}, \mathrm{F}, \mathrm{G}$ \\
\hline$a_{7}$ & $\mathrm{C}, \mathrm{D}$ \\
\hline$a_{8}$ & - \\
\hline$a_{9}$ & $\mathrm{H}, \mathrm{I}, \mathrm{B}$ \\
\hline
\end{tabular}

As presented in table 2 (an example of the Design stage), e.g. task $\mathrm{X}$ with an example number Id $=2.1$ (e.g. Implementation of railway works Railway Station No. 1 - phase I, phase II) contains actual tasks A to G. As a sum task it is not quantitatively correlated with individual risk factors (as related to tasks A to $\mathrm{G})$.

It was indicated only by the designation of " $x$ ", which risk factors occur during the performance of all actual tasks included in its composition. The result of the quantitative correlation in the form of weight-related risk weighting indices assigned to real activities is the result of a detailed query of the contract documentation performed by the implementation team and the conditions under which the planned investment will be implemented.

\footnotetext{
${ }^{3}$ By the real task, the authors understand the action, the duration of which is determined by the planner and does not result from aggregation based on the Designed structure of WBS, that is, summary tasks.
} 
These activities must be performed with great care and accuracy, as they have a significant impact on the final result of the risk analysis.

Then, for each real activity, the most probable date of completing the task with regard to risk factors is calculated. We make the calculation according to the following formula (for Design stage).

$$
\mathrm{T}_{2, \mathrm{j}}=\mathrm{T}_{1, \mathrm{j}}+\left(\sum_{\mathrm{i}=1}^{\mathrm{N}^{\mathrm{D}}} \mathrm{W}_{\mathrm{R}_{\mathrm{i}}}^{\mathrm{DD}} \cdot \mathrm{T}_{1, \mathrm{j}}\right)
$$

where:

$T_{1, j}$ - the original duration of the $\mathrm{j}$-th task,

$T_{2, j}-$ the most probable duration of $j$-th task including risk factors.

Table 2. Allocation of risk factors in the WBS structure of the schedule. Own study based on the source [9].

\begin{tabular}{|c|c|c|c|c|c|c|c|c|c|c|c|c|}
\hline \multirow{2}{*}{ Task name } & \multicolumn{9}{|c|}{ Risk factors affecting individual tasks } & \multirow{2}{*}{ 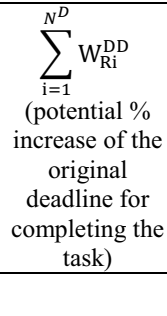 } & \multirow{2}{*}{$T_{1}$} & \multirow{2}{*}{$T_{2}$} \\
\hline & $a_{1}$ & $a_{2}$ & $a_{3}$ & $a_{4}$ & $a_{5}$ & $a_{6}$ & $a_{7}$ & $a_{8}$ & $a_{9}$ & & & \\
\hline $\begin{array}{c}\text { Summary } \\
\text { task X } \\
(\mathrm{Id}=1.1)\end{array}$ & $\mathrm{x}$ & $\mathrm{x}$ & $\mathrm{x}$ & $\mathrm{x}$ & $\mathrm{x}$ & $\mathrm{x}$ & $\mathrm{x}$ & & $\mathrm{x}$ & & & \\
\hline $\mathrm{Id}=2.1 .1 \mathrm{~A}$ & $\mathrm{~W}_{\mathrm{Ri}}^{\mathrm{DD}}$ & & & $\mathrm{W}_{\mathrm{Ri}}^{\mathrm{DD}}$ & & & & & & & & \\
\hline $\mathrm{Id}=2.1 .2 \mathrm{~B}$ & & & $\mathrm{~W}_{\mathrm{R}_{\mathrm{i}}^{\mathrm{rp}}}$ & & & & & & $\mathrm{W}_{\mathrm{Ri}}^{\mathrm{DD}}$ & & & \\
\hline $\mathrm{Id}=2.1 .3 \mathrm{C}$ & $\mathrm{W}_{\mathrm{Ri}}^{\mathrm{DD}}$ & $\mathrm{W}_{\mathrm{Ri}}^{\mathrm{DD}}$ & $\mathrm{W}_{\mathrm{Ri}}^{\mathrm{DD}}$ & $\mathrm{W}_{\mathrm{Ri}}^{\mathrm{DD}}$ & $\mathrm{W}_{\mathrm{Ri}}^{\mathrm{DD}}$ & & $\mathrm{W}_{\mathrm{Ri}}^{\mathrm{DD}}$ & & & & & \\
\hline $\mathrm{Id}=2.1 .4 \mathrm{D}$ & & & $\mathrm{W}_{\mathrm{Ri}}^{\mathrm{DD}}$ & & $\mathrm{W}_{\mathrm{Ri}}^{\mathrm{DD}}$ & $\mathrm{W}_{\mathrm{Ri}}^{\mathrm{DD}}$ & $\mathrm{W}_{\mathrm{Ri}}^{\mathrm{DD}}$ & & & & & \\
\hline $\begin{array}{c}\text { Summary } \\
\text { task X } \\
(\mathrm{Id}=1.2)\end{array}$ & $\mathrm{x}$ & $\mathrm{x}$ & & $\mathrm{x}$ & $\mathrm{x}$ & $\mathrm{x}$ & $\mathrm{x}$ & & $\mathrm{x}$ & & & \\
\hline $\mathrm{Id}=2.1 .5 \mathrm{E}$ & & & & $\mathrm{W}_{\mathrm{Ri}}^{\mathrm{DD}}$ & $\mathrm{W}_{\mathrm{Ri}}^{\mathrm{DD}}$ & $\mathrm{W}_{\mathrm{Ri}}^{\mathrm{DD}}$ & & & & & & \\
\hline $\mathrm{Id}=2.1 .6 \mathrm{~F}$ & & $\mathrm{~W}_{\mathrm{Ri}}^{\mathrm{DD}}$ & & & & $\mathrm{W}_{\mathrm{Ri}}^{\mathrm{DD}}$ & & & & & & \\
\hline $\mathrm{Id}=2.1 .7 \mathrm{G}$ & & $\mathrm{W}_{\mathrm{Ri}}^{\mathrm{DD}}$ & & & & $\mathrm{W}_{\mathrm{Ri}}^{\mathrm{DD}}$ & & & & & & \\
\hline $\mathrm{Id}=2.1 .7 \mathrm{H}$ & $\mathrm{W}_{\mathrm{Ri}}^{\mathrm{DD}}$ & & & & & & & & $\mathrm{W}_{\mathrm{Ri}}^{\mathrm{DD}}$ & & & \\
\hline $\mathrm{Id}=2.1 .7 \mathrm{I}$ & & & & & & & & & & & & \\
\hline $\mathrm{Id}=2.1 .7 \mathrm{~J}$ & & & & & & & & & $\mathrm{~W}_{\mathrm{Ri}}^{\mathrm{DD}}$ & & & \\
\hline
\end{tabular}


As a consequence of the above activities, project teams will receive modified durations of all actual tasks, which, when applied to the baseline, form an updated version of the schedule taking into account the risk (Figure 2). From the schedule prepared in this way, it will be very easy to read the calculated values of deviations from the basic, original implementation dates, both for individual real tasks, summary tasks or assumed milestones.

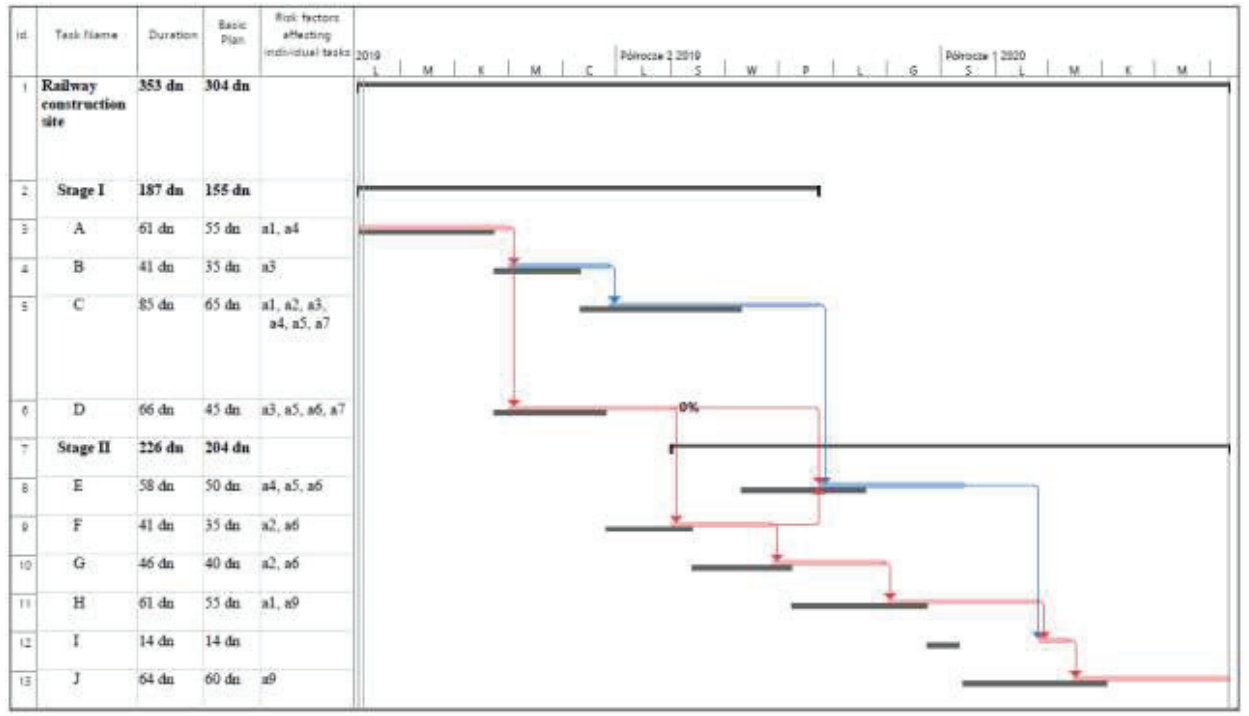

Fig. 2. Sample base plan and schedule update after taking into account the results of the risk analysis.

\section{CONCLUSIONS}

Each construction project is different from the previous ones, and the risks that may occur during their implementation are difficult to predict. Therefore, new methods of assessing and quantifying risk are still being sought. This also applies to railway investments, which are usually implemented in very difficult conditions, with numerous technical, technological and organizational limitations. Current computer programs that support risk analysis are complex, expensive and require data that are often difficult to access or unreliable. The primary goal of the Authors was to develop a method that will allow the possible identified threats to be transferred to the schedule of the planned railway project and its WBS structure. It was assumed that despite the necessary simplifications, the method, relatively easy to implement, based on the list of previously identified threats and their 
quantitative assessment, supported by an appropriate computational program, will encourage teams planning implementation of railway investments for its implementation and will contribute to increasing the reliability of planned deadlines and costs. An additional advantage of the proposed method is the fact that it can be used by both the investor and contractors, at various stages of the works' progress and with its help it is relatively easy to develop emergency management plans for each railway project.

\section{REFERENCES}

1. A. Czarnigowska, A. Sobotka, „Zależność czas-koszt w przewidywaniu czasu realizacji budowy”, Budownictwo I Architektura, 12(1), 23-30, 2013.

2. A. Dziadosz, A. Tomczyk, O. Kapliński, "Financial risk estimation in construction contracts", Procedia Engineering, 122, 120-128, 2015.

3. A. Kazaz, S. Ulubeyli, N.A. Tuncbilekli, „Causes of delay in costruction projects in Turkey”, Journal of civil Engineering and Management 18(3), 426-435, 2012.

4. A. Leśniak, E. Plebankiewicz, "Opóźnienia w robotach budowlanych", Zeszyty Naukowe WSOWL (157), vol: (3), 332-339, 2010.

5. A.S. Faridi, S.M. El-Sayegh, "Sagnificant factors causing delay in UAE construction industry", Constructionn Management and Economics 24, 1167-1176, 2006.

6. C. Kaliba, M. Muya, K. Mumba, „Cost escalation and schedule delays in road cosntruction projects in Zambia”, International Jaournal of Propject Management 27, 522-531, 2009.

7. D.W.M. Chan, M.M. Kumaraswamy, „A comparative study of causes of time overruns in Hong Kong construction projects", International Journal of Project Management 15, 55-63, 1997.

8. D. Skorupka, Quantification and allocation of risk factors in network construction schedules. Science notebooks/ Tadeusz Kosciuszko Land Forces Military Akademy, 145-159, 2008, (in Polish).

9. D. Skorupka, "Method of identifying and assessing the risk of implementing construction projects", WAT, Warsaw 2007, (in Polish).

10. E. Szafranko, "Evaluation of Data Obtained from Expert Opinions in Multi-Criteria Analyses of Construction Investment Variants", Archives of Civil Engineering, vol: 62 (2), 2016.

11. H. Anysz, A. Zbiciak, „Przyczyny powstawania opóźnień w realizacji kontraktów budowlanych - analiza wstępnych wyników badania ankietowego", Autobusy (3/14), DW Spatium, 2013.

12. H. Doloi, A. Sawhney, K.C. Iyer, S. Rentala, "Analysing factors affecting delays in Indian construction project”, International Jorunal of Project Management 30, 479-489, 2012

13. J. Bizon-Górecka, J. Górecki, "Ryzyko projektu inwestycyjno-budowlanego w perspektywie formuły jego realizacji”, Studies \& Proceedings of Polish Association for Knowledge Management, 2015/3/1, (74), s4-15, 2015.

14. J. Kowalski, M. Polonski, "Indentification of hazards related with the stakeholders group during railway investments in Poland" ACTA Architektura, 16 (4), 83-92, 2017, (in Polish).

15. J. Kowalski, M. Polosnki, "Identification of risk investment using the risk matrix on railway facilities", Open Eng. 8, 506-512, 2018

16. M. Polonski, J. Kowalski, "Problems at the stage to agree project documentation for railway contracts using FIDIC Conditions of Contract", Materiały Budowlane, no 6, 162-163, 2016, (in Polish).

17. M. Polonski, J. Kowalski, "The identification of hazards concerning the character of construction works on railway sites in Polnad" Technical transactions 5, 47-55, 2017.

18. M. Polonski, K.Pruszynski, "Probalistyczne aspekty procesu budowlanego cz.2", Przegląd budowlany 12, 4953, 2006.

19. P. Jaśkowski, "Methology for enhancing reliability of predicive project schedules in construction", Maintenance and Reliability, 17 (3), s. 470-479, 2015.

20. R. Marcinkowski, \& A. Koper, “Ocena ryzyka czasu i kosztów w planowaniu produkcji budowlanej”, Przegląd Budowlany, 7/8, 70-75, 2008.

21. S. Biruk, P. Jaskowski, "The conceptual framework for construction project risk assessment", Reliability: Theory \& Applications, 03 (22, Vol.2), 27-35, 2010. 
22. O. Kapliński, "Risk Management of Construction Works by Means of the Utility Theory: a Case Study", Procedia Engineering, 57, 533-539, 2013.

23. Y. Frimpong, J. Oluwoye, L. Crawford., "Causes of delay and cost overruns in construction of droundwater projects in a developing countries", Ghana as a case study, International Jornal of Project Management 21, $321-326,2003$

\section{LIST OF FIGURES:}

Tab. 1. Correlation of real tasks of the summary task X with risk factors.

Tab. 1. Korelacja operacji przedsięwzięcia X z czynnikami ryzyka.

Tab. 2. Allocation of risk factors in the WBS structure of the schedule.

Tab. 2. Alokacja czynników ryzyka w strukturze podziału pracy.

Fig. 1. Sample base plan and schedule update after taking into account the results of the risk analysis

Rys. 1. Przykładowy plan bazowy i aktualizacja harmonogramu po uwzględnieniu wyników analizy ryzyka.

\section{METODA PLANOWANIE REALIZACJI INWESTYCJI KOLEJOWYCH Z UWZGLĘDNIENIEM RYZYKA}

Keywords: identyfikacja zagrożeń, ryzyko, inwestycje kolejowe, planowanie robot budowlanych, matryca ryzyka.

\section{SUMMARY:}

Prawie każda inwestycja budowlana, powinna zawierać elementy prognozowania ryzyka, których trafność jest uzależniona między innymi od prawidłowej oceny potencjalnych zagrożeń. Zagrożenia te zostały przez Autorów zdefiniowane jako czynniki ryzyka, które zostały scharakteryzowane a następnie zgrupowane na podstawie wykonanych badań w zakresie ich identyfikacji. W związku z tym, że na rynku budowlanym nie ma metody harmonogramowania inwestycji kolejowych z uwzględnieniem oceny ryzyka, podjęto wysiłek badawczy [14-17], którego efektem jest proponowana metoda. W artykule przedstawiono główne założenia oryginalnej metody harmonogramowania inwestycji kolejowych, która z jednej strony uwzględni wpływ potencjalnych, zidentyfikowanych wcześniej przez autorów specyficznych dla inwestycji kolejowych zagrożeń, a z drugiej pozwoli menadżerom projektu odnieść je do warunków, w jakich planowana jest realizacja konkretnego obiektu. Przyjęto założenie, że stosunkowo prosta we wdrożeniu metoda, wsparta odpowiednim programem obliczeniowym, zachęcie zespoły planujące realizację przedsięwzięć kolejowych do jej stosowania i zwiększy wiarygodność opracowywanych przez nie harmonogramów.

Received 15.04.2019

Revised 30.04.2019 
